\title{
Incorporating Queer, Housing Insecure Perspectives into Eucharistic Theology
}

\section{Barbara Anne Kozee Jesuit School of Theology (Berkeley, CA)}

The embodied nature of our Christian faith has been distinctly enriching at the same time as it has posed significant challenges. A gift of our belief in divine embodiment through Christ has been our tradition's sacralization of the human body, a true grace for those of us who consistently fail at seeing ourselves as beautiful, made in the image of God. Bodily shame has corrupted our communion with God and each other, and this has significantly impacted Christian embodied theology, proving our faith to be one of prophetic vision for what freedom and liberation truly mean as well as a human institution that has been unambiguously oppressive and cruel. To concretize this statement, consider how M. Shawn Copeland's Enfleshing Freedom reveals the way that traditional theological anthropology has failed the American Black woman.

Copeland beautifully articulates the tension between enrichment and challenge for those on the margins of Christian theology when she ends her book saying "Jean-Luc Marion writes that 'theology, of all writing... causes the greatest pleasure.' For the theologian of the [B]lack experience, writing theology may also evoke the deepest sorrow, the deepest gratitude, the deepest love." ${ }^{1}$ This paper hopes to continue a Copeland-esque tradition of deep sorrow, gratitude, and love for the faith by considering the relationship between the Eucharist and desire in a way that centers the LGBTQ person who experiences housing insecurity and homelessness.

\footnotetext{
${ }^{1}$ M. Shawn Copeland, Enfleshing Freedom: Body, Race, and Being, (Minneapolis: Fortress Press, 2010), 130.
} 


\section{KOZEE: INCORPORATING QUEER, HOUSING INSECURE PERSPECTIVES}

Perhaps the reason that treating embodiment within the Christian tradition can be troubling has been our murky relationship with the concept of desire. ${ }^{2}$ As resistance to shamebased frameworks of theology, this paper aims to understand the Eucharist through a lens of desire and to map this onto the material world. This paper argues that the Christian Eucharistic tradition is one of radical table fellowship. The root of the practice is a reorienting and subversive desire for intimate communion with the margins. Secondly, this paper will use socioeconomic data on the relationship between race, sexual and gender identity, and homelessness to argue that our desires are materially consequential and interconnected. This will lead to a conversation on temporality as it relates to the Eucharist, queerness, and social change. This paper will show that a Eucharistic theology that stays faithful to its tradition of radical table fellowship rooted in desire of and for the margins requires economic liberation that seriously imagines ending homelessness in the here-and-now.

\section{Exploring the Eucharistic Tradition}

While the Eucharistic tradition is often seen as a sacrament built upon communion and fellowship, queer Christian theologians have interrogated this concept further and supposed that "erotic energy sits at the heart of the Christian faith and practice." 3 Jay Johnson's Divine Communion begins with this notion, moving from the biblical comparison between the Eucharist and the image of a wedding banquet. Johnson builds off of a queer tradition that has tried to interrogate the depths of desire. Audre Lorde's chapter on the uses of the erotic defines eroticism as "providing the power which comes from sharing deeply any pursuit with another person... The dichotomy between the spiritual and the political is [false], resulting from an incomplete

\footnotetext{
${ }^{2}$ Here, I think specifically of Augustine on the teleology of sex and Catholic Social Teaching's overemphasis on the procreative nature of sexual relationships. For more on the history of sex in the Christian tradition, see Margaret Farley, Just Love: A Framework for Christian Sexual Ethics, (New York: Continuum, 2006).

${ }^{3}$ Jay Johnson, Divine Communion, 3.
} 


\section{KOZEE: INCORPORATING QUEER, HOUSING INSECURE PERSPECTIVES}

attention to our erotic knowledge. For the bridge that connects them is formed by the erotic... the passions of love, in its deepest meanings." ${ }^{4}$ For Johnson, Lorde, queer theorists, and queer theologians, eroticism is an energy that includes but is not limited to the sexual and that is rooted in a deep desire for intimacy and union. In this essay, desire is erotic and transcendent of our modern spheres of distinction; it is Lorde's bridge. Eroticism is an integrating force that allows us to love ourselves and to love others in all of our complexities. Erotic desire, more than the common interpretations of Eucharist as agape friendship or accompaniment, allows us to view the sacrament as an invitation into an all-encompassing desire, a yearning for bodily love and acceptance. Let us return to the newly bold claim, then, that the Eucharist is the erotic desire of and for the margins and begin with Jesus's practice of meal sharing.

Jesus's Eucharistic table fellowship is described as radical because he is widely acknowledged by biblical scholars to have eaten with sinners throughout the New Testament (Matt 11:19; Mark 2:15; Luke 7:34, 15:12, 19:7). ${ }^{5}$ Julie Rubio gives a succinct overview of traditional and recent scholarship on the sociocultural elements of Jesus's table fellowship in her book Family Ethics. Jesus's table was a scandalous one for the ancient Near Eastern world that he lived in, especially for the clerical elite who were critical of his disrespect for purity law, which forbade eating with sinners. Jesus's meal-sharing practices challenged social hierarchies. Meals operated as symbols of social structure that reinforced the honor/shame code of the ancient Near Eastern culture in first-century Palestine. ${ }^{6}$ For this reason, Rubio notes that "eating with sinners or social outcasts made no sense." Instead of remaining complicit with the isolating

\footnotetext{
${ }^{4}$ Audre Lorde, "Uses of the Erotic" in Sister Outsider: Essays and Speeches, (Trumansburg, NY: Crossing Press, 1984), 56.

5 Julie Hanlon Rubio, Family Ethics: Practices for Christians, (Washington, D.C: Georgetown University Press, 2010), Kindle Location 1803.

${ }^{6}$ Ibid, Kindle Location 1817-1843.

${ }^{7}$ Julie Rubio, Family Ethics, Kindle Location 1845.
} 


\section{KOZEE: INCORPORATING QUEER, HOUSING INSECURE PERSPECTIVES}

and hierarchical cultural norms of his time, Jesus resisted through a desire to know those whose knowing was highly discouraged. This challenged the very social function of the shared meal itself. Jesus disrupted a cultural symbol of division by flipping it on its head. Today, we might call these meals acts of protest or cultural resistance. Responding to scholarship that posits that Jesus ate with sinners in order to offer them forgiveness and salvation, Rubio reminds us that Jesus "ate with sinners before any discussion about salvation had taken place, before any new promises had been made. Jesus's choice of eating companions must mean something more." Here, we can begin to see the role of desire in Eucharistic table fellowship. Not only was Jesus's table anti-hierarchical, it was also a table of grace, a table of being without any expectation of what becoming will look like. I argue that being without expectation was Jesus's expression of erotic desire for the margins. Jesus did not eat with the margins in order to save them, but to intimately know them.

Jesus's table fellowship is made important via his final meal celebration with some of his closest friends, what we refer to as the Eucharist. The cultural and historical significance of Jesus's meals is sacralized in the eschatology of the Eucharist that collapses the past into the present into the future. Copeland describes Eucharist as "that inalienable gift that anchors believers in time, connects them one to another as well as to their origin, [and] intimates their future." ${ }^{9}$ Systematic theologians have contended that the past, the present, and the future are all present in the Eucharistic sacrament. In this way, the Christian vision of God supersedes time and indeed supersedes our ability to fathom time. Johnson comments that the eschatological imagination of Eucharistic practice "continually feeds that vision of being at home with one another free of violent oppressions, where the glory of bodily intimacy shines freely and

\footnotetext{
8 Julie Rubio, Family Ethics, Kindle Location 1841-1842.

${ }^{9}$ M. Shawn Copeland, Enfleshing Freedom, 108.
} 


\section{KOZEE: INCORPORATING QUEER, HOUSING INSECURE PERSPECTIVES}

unimpeded by the controlling forces of empire, regardless of the form those forces take." ${ }^{10}$ For Johnson, Eucharistic eschatology is imaginative and unhindered by the various manifestations of empire across human cultures. John Zizoulas also shows the eschatological significance of the Eucharistic table. He highlights the troubling issue for Christians of how to make meaning of the Eucharist in a society post-crucifixion yet living before the end times. This issue is resolved in the presence of the Holy Spirit, a trinitarian theology of divine presence. ${ }^{11}$ The trinitarian God remains present and active in the Eucharistic celebration and allows for a transcendence and collapsing of time, seen in descriptions from the book of Revelation that show how "the Eucharist should not be considered as a reality parallel to heaven, but as identical to it."12 The Christian ritualization and institutionalization of radical table fellowship with the margins is rooted in these eschatological aspects of the Eucharistic sacrament, where many become one in heavenly moments of union. I move toward a particularly queer relationship to housing justice that takes seriously socioeconomic data about housing insecurity and homelessness and that understands Lorde's erotic, integrating bridge between sexual and material desires.

\section{Housing Justice as Queer Desire}

Housing insecurity and homelessness disproportionately affect the LGBTQ community. A theological interpretation of this data shows that our sexual desires can inform our material desires and that there is a responsibility of the Eucharistic table to meet the needs of queer people. Recognizing the interconnectedness of different manifestations of erotic desire brings us beyond a table of tokenization toward one of true intimacy.

\footnotetext{
10 Jay Johnson, Divine Communion, 87.

${ }^{11}$ John Zizoulas, "Biblical Aspects of the Eucharist" in The Eucharistic Communion and the World, (New York, NY: Bloomsbury Publishing, 2011), 7-8.

12 Ibid, 17.
} 


\section{KOZEE: INCORPORATING QUEER, HOUSING INSECURE PERSPECTIVES}

Establishing housing justice as queer erotic desire can be accomplished through an interrogation of persisting and recent data on queer identity and homelessness. While LGBTQ youth comprise $5 \%$ to $8 \%$ of the U.S. youth population, they make up at least $40 \%$ of youth experiencing homelessness..$^{13} 46 \%$ of homeless LGBT youths ran away because of family rejection of their sexual orientation or gender identity; $43 \%$ were forced out by parents, and $32 \%$ faced physical, emotional or sexual abuse at home. ${ }^{14}$ It is clear from these statistics that disclosing sexual or gender identity can put youth at risk of violence and severe trauma. Much of the conversation around LGBTQ homelessness has been shaped by these devastating statistics regarding queer youth, but recent data suggests that housing insecurity persists into LGBTQ adulthood. A May 8, 2020 press release from UCLA School of Law details the findings of the first study of its kind to provide estimates for the percentage of sexual and gender minority adults experiencing homelessness. The findings show that $17 \%$ of sexual minority adults have experienced homelessness in their lifetime, compared to $6 \%$ of the general population. ${ }^{15}$ Sexual minorities suffer homelessness at more than double and close to triple the rates of straight people. The breakdown of who is being impacted by homelessness can also be seen along the lines of race and gender.

According to the same UCLA study, 6\% of LGBTQ African Americans experienced recent housing instability, compared to $3 \%$ of Latinx queers and $2 \%$ of white queers. ${ }^{16}$ Further,

\footnotetext{
${ }^{13}$ Brandon Andrew Robinson, "Conditional Families and Lesbian, Gay, Bisexual, Transgender, and Queer Youth Homelessness: Gender, Sexuality, Family Instability, and Rejection." Journal of Marriage and Family, 80, no. 2, $2018,383$.

${ }^{14}$ Williams Institute. "Serving Our Youth: Findings from a National Survey of Services Providers Working with Lesbian, Gay, Bisexual and Transgender Youth Who Are Homeless or At Risk of Becoming Homeless." UCLA School of Law, accessed 18 May 2020.

${ }^{15}$ Williams Institute, "Sexual minority adults twice as likely as the general population to have experienced homelessness," UCLA School of Law, accessed 18 May 2020.

${ }^{16}$ Ibid.
} 


\section{KOZEE: INCORPORATING QUEER, HOUSING INSECURE PERSPECTIVES}

the National Center for Transgender Equality reports that $20 \%$ of transgender individuals have experienced homelessness at some point, and $10 \%$ of trans people have been evicted because of their gender identity. ${ }^{17}$ The data shows that, within the LGBTQ community, housing insecurity persists as an issue into adulthood, with racial minorities and trans individuals disproportionately affected.

The experiences of the queer community show that understanding your sexual and gender identity, choosing to reject shame, and embracing your body can and do result in the loss of housing and basic needs, a relationship that is located within systemic racial injustices. In this way, sexual and romantic desire appear as materially consequential. Further, queer people often must choose between these desires: Am I safe to hold my partner's hand here? Is the emotional or physical harm that I endure in my household worth the roof over my head? To an extreme extent within the lives of queer and trans people who have experienced homelessness, especially people of color, and to a subliminal extent within the lives of the entire queer community, the relationship between sexual and material desire is a constant negotiation.

Lorde suggests that "once we begin to feel deeply all the aspects of our lives, we begin to demand from ourselves and from our life-pursuits that they feel in accordance with that joy which we know ourselves to be capable of." 18 Feeling the liberation of our queer sexual desires can inform our desire to seek this joy and liberation from our economic frameworks as well. The queer community has something important to say about material concerns regarding housing and shelter as a human right, and a Eucharistic theology that authentically desires the margins must desire their fullness. Without this commitment, including queer people at the table is simply

\footnotetext{
17 "Housing and Homelessness," National Center for Transgender Equality, accessed 18 May 2020.
}

${ }^{18}$ Audre Lorde, "Uses of the Erotic" in Sister Outsider, 57. 


\section{KOZEE: INCORPORATING QUEER, HOUSING INSECURE PERSPECTIVES}

tokenization. Because of our Eucharistic tradition that calls us to erotic intimacy, this should not be a peripheral concern but rather a central concern of faith-based housing justice movements.

\section{Eucharist, Queer Temporality, and Social Change}

Eucharistic theology that desires queer people requires seeking economic liberation and imagining an end to homelessness in the here-and-now. The final section of this paper will explore the relationship between the Eucharist and immediacy related to our economic decisions. The temporal, sacred mystery of the Eucharist problematizes modern, gradual frameworks of change that serve to desacralize time. The queer-inclusive Eucharistic table expands our horizons of possibility and reminds us of the radical potentiality of every infinite future-present, of our own personal and collective agency to enact change in the world around us. Queer and decolonial theory can help to articulate this relationship between erotic desire, Eucharist, temporality, and social change.

A disruption of liberal claims to linear and historical progress lies at the heart of much of queer and decolonial theory. ${ }^{19}$ This disruption allows us to consider the ways that power continues to be reproduced across space and time and permits us to imagine futures that we may never achieve. José Esteban Muñoz famously begins his book Cruising Utopia with the notion that "queerness is not yet here... We have never been queer, yet queerness exists for us as an ideality that can be distilled from the past and used to imagine a future. The future is queerness's domain.. ${ }^{20}$ For Muñoz, queerness is imaginative and future-oriented. It has an eschatological nature oriented toward a future that we may never achieve, and, as queers, we are comfortable

\footnotetext{
${ }^{19}$ Imagine the "It gets better" narrative that accompanies coming out or the centering of marriage equality in the fight for queer rights in the United States. While neither of these narratives is necessarily harmful, neither centers the material safety of queer and trans people, especially people of color, in the ways mentioned throughout this paper.

20 José Esteban Muñoz, Cruising Utopia: The Then and There of Queer Futurity, (New York: New York University Press, 2019), 1.
} 


\section{KOZEE: INCORPORATING QUEER, HOUSING INSECURE PERSPECTIVES}

sitting with this liminality, complexity, and unattainable beauty. This is the framework in which we can find a queer inclusive Eucharistic theology.

Queer theologian Elizabeth Stuart shows that laughter in the face of death represents a queering of and, therefore, a returning to the Eucharistic tradition of radical hope that lies in resurrection. She emphasizes that a Christian death is uniquely camp and comedic because of Christ's resurrection. ${ }^{21}$ If we as Christians truly believe in the afterlife as we say we do, then the human fear of death is the biggest joke of all, with the resurrection as its greatest punchline. Stuart reminds us that the risus paschalis, or Easter laughter, was a feature of the Easter ritual in some parts of medieval Europe. This ritual involved pastors "using earthy humour" on Easter in order to make the congregation laugh. ${ }^{22}$ Stuart's queering of death shows us that we can--and indeed are required to as Christians--approach Muñoz's queer futurity with a sense of joy and courage. In this way, a lived Eucharistic practice is fearless because we know that empire, capitalism, and oppression are not how the story ends, even as we struggle to imagine the kindom of God. Queer Eucharistic theology guides us back to this part of our Christian tradition.

Finally, postcolonial theology has argued for viewing the future as currently emergent and has observed the hope that accompanies this perspective. ${ }^{23}$ Queering and decolonizing the Eucharist may therefore mean hope for an emerging future that approaches social change through seeing the sacred value and possibility of each moment. Every moment that homelessness continues to be a reality within our economic framework is a moment that fails to live out Eucharistic union and disrespects the queer people experiencing homelessness and

${ }^{21}$ Elizabeth Stuart, "Queering Death" in The Sexual Theologian: Essays on Sex, God, and Politics, ed. Marcella Althaus-Ried and Lisa Isherwood, (New York: T\&T Clark, 2004), 60-62.

${ }^{22} \mathrm{Ibid}, 65$.

${ }^{23}$ Catherine Keller, "The Love of Postcolonialism: Theology in the Interstices of Empire," in Postcolonial Theologies: Divinity and Empire, ed. Catherine Keller, Michael Nausner, and Mayra Rivera, (St. Louis, MO: Chalice Press, 2012), 229. 


\section{KOZEE: INCORPORATING QUEER, HOUSING INSECURE PERSPECTIVES}

housing insecurity that are a part of our community. Every future-present that normalizes the idea that housing is not a human right scandalizes our Christian faith and contributes to the imperfect celebration of the Eucharist at our weekly liturgies. Incorporating postmodern frameworks for social change that accompany communion with queer people and our tradition will require striving to bring an end to homelessness into the here-and-now.

The previous sections of this essay have established the Eucharist as radical table fellowship that represents a distinctly erotic desire of and for the margins, a reality that makes Christians responsible for considering the way that our economic frameworks are harming the most vulnerable members of the queer community. When imagining social change around these issues, queer and decolonial theory allow us to embrace the unattainable, to laugh in the face of death/impossibility, and to view the future as the here-and-now. When the troubling, practical realities regarding housing and homelessness in the queer community often require reactionary policies and responses, a queer Eucharistic theology allows us to imagine abundance and what it could mean to live in a more just and hopeful world where housing is a human right.

Ultimately, viewing the Eucharist as an erotic desire for intimacy with queer people that includes their material concerns means that people of faith must move from complacency to immediate action in a way that would radically shift our economic institutions and their approach to resource allocation. Immediate action is hard for us to conceive in the U.S. where bureaucracy prevails, but I believe that we must expand our moral imagination if we are to stay faithful to Christ's commitment to listening and being at those radical meals of table fellowship all those years ago. The Eucharist is a hopeful taste of heaven and should serve as a reminder of the sacredness and rich potential for change and reconciliation embedded in every moment of being 


\section{KOZEE: INCORPORATING QUEER, HOUSING INSECURE PERSPECTIVES}

alive. Once we start living like this, we will be one step closer to glimpsing that heavenly wedding banquet that we yearn for each Sunday.

\section{Bibliography}

Copeland, M. Shawn. Enfleshing Freedom: Body, Race, and being. Minneapolis: Fortress Press, 2010.

Johnson, Jay Emerson. Divine Communion: A Eucharistic Theology of Sexual Intimacy. New York: Seabury Books, 2013.

Keller, Catherine. "The Love of Postcolonialism: Theology in the Interstices of Empire," in Postcolonial Theologies: Divinity and Empire, ed. Catherine Keller, Michael Nausner, and Mayra Rivera, (St. Louis, MO: Chalice Press, 2012).

Lorde, Audre. "Uses of the Erotic," in Sister Outsider: Essays and Speeches. Trumansburg, NY: Crossing Press, 1984.

Muñoz, Jose. Cruising Utopia: The Then and There of Queer Futurity. New York: New York University Press, 2019.

National Center for Transgender Equality, "Housing and Homelessness," https://transequality.org/issues/housing-homelessness (accessed May 18, 2020).

Rubio, Julie Hanlon. Family Ethics: Practices for Christians. Washington, D.C: Georgetown University Press, 2010.

Robinson, Brandon Andrew. "Conditional Families and Lesbian, Gay, Bisexual, Transgender, and Queer Youth Homelessness: Gender, Sexuality, Family Instability, and Rejection." Journal of Marriage and Family, 80, no. 2, 2018.

Stuart, Elizabeth. "Queering Death," in The Sexual Theologian: Essays on Sex, God, and Politics. Ed. Marcella Althaus-Ried and Lisa Isherwood. New York: T\&T Clark, 2004.

Williams Institute. "Serving Our Youth: Findings from a National Survey of Services Providers Working with Lesbian, Gay, Bisexual and Transgender Youth Who Are Homeless or At Risk of Becoming Homeless." UCLA School of Law. https://williamsinstitute.law.ucla.edu/publications/serving-our-youth-lgbtq/ (accessed May 18, 2020).

Williams Institute. "Sexual minority adults twice as likely as the general population to have experienced homelessness." UCLA School of Law. 


\section{KOZEE: INCORPORATING QUEER, HOUSING INSECURE PERSPECTIVES}

https://williamsinstitute.law.ucla.edu/press/lgbt-homelessness-press-release/ (accessed May 18, 2020).

Zizoulas, John. "Biblical Aspects of the Eucharist," in The Eucharistic Communion and the World. New York: Bloomsbury Publishing, 2011. 